\title{
Penile changes due to genital pearling (fang muk)
}

\section{Zmiany w obrębie prącia związane z procedurą genital pearling (fang muk)}

Przegl Dermatol 2017, 104, 64-65

DOI: https://doi.org/I0.5 | |4/dr.2017.66224

A 41-year-old man of Thai origin was referred to the Department of Dermatology due to acute, generalized eczema. Otherwise, the medical history was unremarkable and the patient denied taking any medications. Physical examination of external genital organs revealed multiple, asymptomatic, hard, subcutaneous nodules, immovable to the underlying tissue within the penis shaft (Figure 1). The patient denied any problems with urination and sexual function. What is worth mentioning, he did not seem to be concerned about penile lesions. Initially we had trouble with establishing a diagnosis due to a language barrier. After meticulous enquiry the nodules turned out to be glass beads obtained from a plastic dispenser placed inside a bottle of vodka, implanted consecutively within the 2 previous years. Genital pearling was a very popular procedure among the patient's Thai friends and is often performed by nonprofessionals, as in the present case. Laboratory tests including complete blood count, standard biochemistry, C-reactive protein, urine analysis, as well as tests for syphilis, hepatitis B virus (HBV), hepatitis $C$ virus $\mathrm{HCV}$ and human immunodeficiency virus (HIV) were within the normal range or negative. Oral

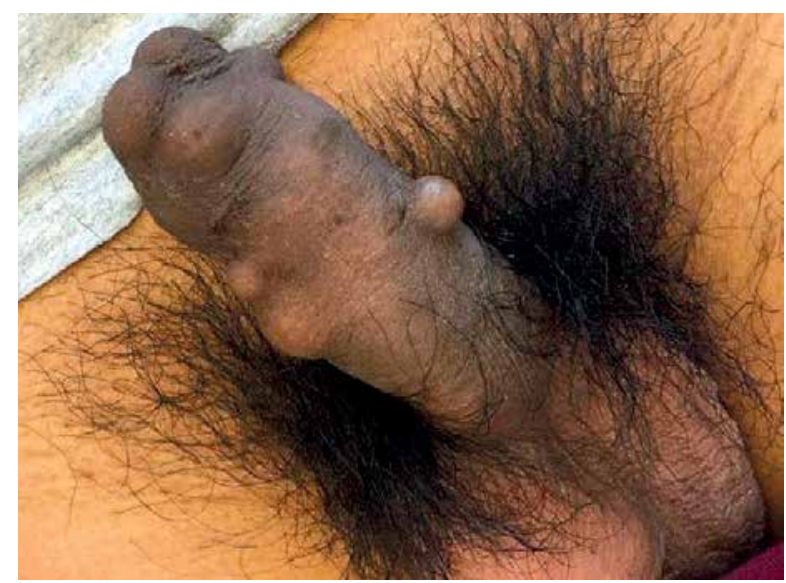

Figure I. Asymptomatic subcutaneous nodules within the penis shaft

Rycina I. Asymptomatyczne podskórne guzy w obrębie trzonu prącia prednisone treatment recommended for generalized eczema proved to be successful. The results of epidermal patch tests performed afterwards were negative. The patient was asked to bring a sample glass ball for the follow-up visit (Figure 2). After 6 months of follow-up he remained asymptomatic.

Genital pearling (genital beading, fang muk, bulletus, chagan balls, tancho balls, and penis marbles) is a body modification procedure which involves inserting foreign bodies of different shape, material and origin into the subcutaneous tissue of genital organs. The roots of genital pearling probably date back to the $18^{\text {th }}$ century, and originate from the tradition of Japanese yakuza. The name 'pearling' derives from pearls that were originally used for the procedure. Nowadays, it is popular in some Asian populations - especially among men from lower socioeconomic groups and prisoners $[1,2]$. The procedure is performed as

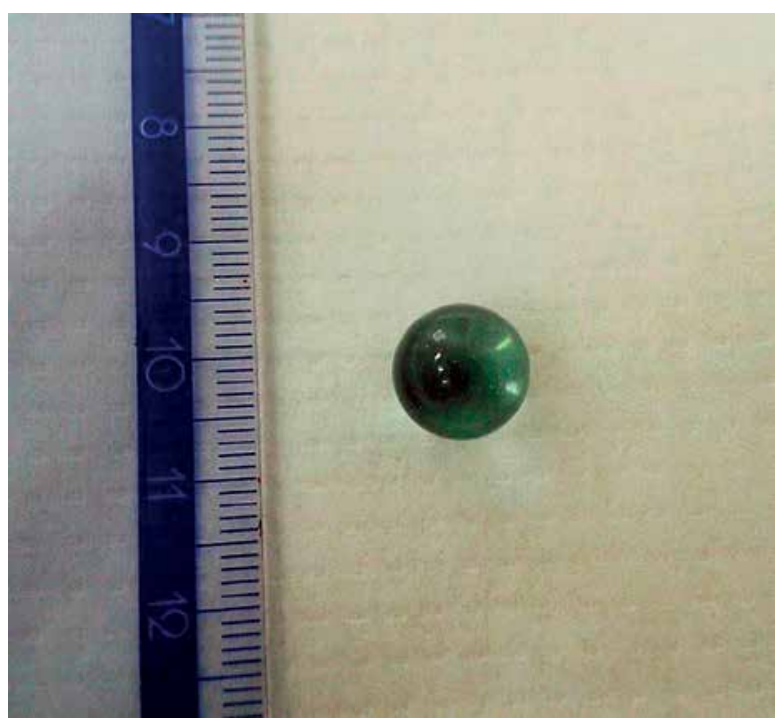

Figure 2. A sample glass bead obtained from a plastic dispenser placed inside a bottle of vodka used in the procedure in the present case

Rycina 2. Szklana kulka uzyskana z plastikowego nalewaka umieszczonego w szyjce butelki od wódki, którq wykorzystano do procedury w opisywanym przypadku 
a body ornamentation technique or to increase sexual pleasure. In the present case there were no associated complications, but possible complications include local or systemic infection, allergic foreign body response, fibrosing leading to pain and erectile dysfunction, and damage to the anatomic structures.

In the differential diagnosis of artificial penile nodules, cysts, calcification or ossification, sclerosing lipogranuloma, silicone granuloma, mucocele, and subcutaneous angiitis should be considered. Nevertheless, the stony hardness of nodules in palpation usually allows one to confirm the diagnosis [3].

Due to the increasing scale of immigration, similar cases will probably occur more frequently.

Received: $4 \times 2016$

Accepted: 27 I 2017

\section{References}

1. Yap L., Butler T., Richters J., Malacova E., Wand H., Smith A.M., et al.: Penile implants among prisoners-a cause for concern? PLoS One 2013, 8, e53065.

2. Fischer N., Hauser S., Brede O., Fisang C., Müller S.: Implantation of artificial penile nodules - a review of literature. J Sex Med 2010, 7, 3565-3571.

3. Lim K.B., Seow C.S., Tulip T., Daniel M., Vijayasingham S.M.: Artificial penile nodules: case reports. Genitourin Med 1986, 62, 123-125.

Martyna Sławińska, Michał Sobjanek, Joanna Dawicka, Joanna Kłudkowska, Roman Nowicki Department of Dermatology, Venerology and Allergology, Medical University of Gdansk, Gdansk, Poland 